\title{
MERGER, AKUSISI DAN KONSOLIDASI DALAM PERSPEKTIF HUKUM PERSAINGAN USAHA
}

\author{
Paulus Aluk Fajar Dwi Santo \\ Jurusan Manajemen, Fakultas Ekonomi dan Bisnis, Bina Nusantara University \\ Jln. K.H. Syahdan No. 9, Kemanggisan, Palmerah, Jakarta Barat 11480 \\ paulus_afds@binus.edu
}

\begin{abstract}
Mergers, acquisitions and consolidation is a business strategy that is commonly used in the business world to be able to build competitive advantage company, which in time can enhance shareholder value while maximizing the prosperity of the company owners or shareholders. To achieve the above objective normative, policy-makers need a plan and steps of strategic and accurate information to avoid the risk of failure. However, the strategy of merger, acquisition and consolidation of certain potentially inhibit fair competition conditions, thus becoming one of the objects that need to be regulated in Law no. 5 Year 1999 concerning Prohibition of Monopolistic Practices and Unfair Business Competition. Market impact of mergers, acquisitions and consolidation is important for analysis because it can have significant legal consequences for businesses, so that the research method used is the juridical normative and empirical approaches. In practice of mergers, acquisitions and consolidation intersect with regulation in other sectors, especially banking and capital markets. That is, there should be equality of perception and interpretation among the institutions that issued the policy.
\end{abstract}

Keywords: merger, acquisitions and consolidation

\begin{abstract}
ABSTRAK
Merger, akuisisi dan konsolidasi merupakan strategi bisnis yang lazim digunakan dalam dunia usaha agar mampu membangun keunggulan bersaing perusahaan, yang pada saatnya nanti dapat meningkatkan nilai perusahaan sekaligus memaksimumkan kemakmuran pemilik perusahaan atau pemegang saham. Untuk mencapai tujuan normatif di atas, pembuat keputusan memerlukan rencana dan langkah-langkah strategis serta informasi yang akurat agar terhindar dari resiko kegagalan. Namun demikian strategi merger, akusisi dan konsolidasi tertentu berpotensi menghambat kondisi persaingan yang sehat, sehingga menjadi salah satu objek yang perlu diatur dalam UU No. 5 Tahun 1999 tentang Larangan Praktek Monopoli dan Persaingan Usaha Tidak Sehat.. Dampak pasar dari merger, akusisi dan konsolidasi penting untuk dianalisis karena hal tersebut dapat memiliki akibat hukum yang signifikan bagi pelaku usaha, sehingga metode penelitian yang digunakan adalah secara yuridis normatif dan pendekatan yuridis empiris. Dalam prakteknya kegiatan merger, akuisisi dan konsolidasi bersinggungan dengan regulasi di sektor lain, terutama perbankan dan pasar modal. Artinya, perlu ada kesamaan persepsi dan interpretasi antar lembaga-lembaga yang mengeluarkan kebijakan.
\end{abstract}

Kata kunci: merger, akuisisi dan konsolidasi 


\section{PENDAHULUAN}

Di Indonesia sendiri, hukum persaingan diperkenalkan pada tahun 1999, setelah lebih dari sepuluh tahun disusun pelyang pepemerintah tanpa langkah implementasi yang terstruktur seiring besarnya tekanan konglomerasi pada era tersebut. Tidak dipungkiri bahwa pemenuhan komitmen kepada IMF merupakan salah satu pemicu diimplementasikannya hukum dan kebijakan persaingan di Indonesia. Namun sekarang, pengalaman selama sepuluh tahun terakhir menunjukkan bahwa kebijakan dan hukum persaingan telah menjadi hal yang tidak dapat dipisahkan dalam perkembangan ekonomi nasional, terutama dalam era perdagangan bebas (globalisasi) dalam beberapa tahun terakhir.

Tindakan pengabungan, peleburan dan atau pengambilalihan disadari atau tidak, akan mempengaruhi persaingan antar para pelaku usaha di dalam pasar bersangkutan dan membawa ampak kepada konsumen dan masyarakat, karena itu sesuai dengan amanat Pasal 28 dan 29 UU No. 5 Tahun 1999, Komisi Pengawas Persaingan Usaha akan melakukan pengendalian terhadap penggabungan, peleburan dan atau pengambilalihan yang mengakibatkan berkurangnya tingkat persaingan di pasar bersangkutan dan dapat menimbulkan kerugian masyarakat. Dalam Peraturan Pemerintah Republik Indonesia No. 57 Tahun 2010 Tentang Penggabungan Atau Peleburan Badan Usaha Dan Pengambilalihan Saham Perusahaan Yang Mengakibatkan Terjadinya Praktik Monopoli Dan Persaingan Usaha Tidak Sehat pada Pasal 1 memberikan definisi sebagai: (1) penggabungan adalah perbuatan hukum yang dilakukan oleh satu Badan Usaha atau lebih untuk menggabungkan diri dengan Badan Usaha lain yang telah ada yang mengakibatkan aktiva dan pasiva dari Badan Usaha yang menggabungkan beralih karena hukum kepada Badan Usaha yang menerima Penggabungan dan selanjutnya status Badan Usaha yang mengabungkan diri berakhir karena hukum; (2) peleburan adalah perbuatan hukum yang dilakukan oleh dua Badan Usaha atau lebih untuk meleburkan diri dengan cara mendirikan satu Badan Usaha baru yang karena hukum memperoleh aktiva dan pasiva dari Badan Usaha yang meleburkan diri dan status Badan Usaha yang meleburkan diri berakhir karena hukum; (3) pengambilalihan adalah perbuatan hukum yang dilakukan oleh pelaku usaha untuk mengambilalih saham Badan Usaha mperoleh atau mendapatkan baik seluruh atau sebagian saham dan atau asset Perseroan / Badan Usaha yang mengakibatkan beralihnya pengendalian terhadap Badan Usaha tersebut.

Persaingan usaha yang sehat telah menjadi acuan bagi para pelaku usaha semenjak hadirnya Undang-Undang Nomor 5 Tahun 1999 tentang larangan Paraktik Monopoli Dan Persaingan Usaha Tidak sehat (Undang-Undang Persaingan Usaha). Dibandingkan dengan kebanyakan undang-undang di Indonesia, Undang-Undang Persaingan Usaha adalah satu dari sedikit Undang-Undang Yang berlakui efektif secara langsung karena tidak memerlukan banyak peraturan pemerintah. Dalam batang tubuhnya hanya terdapat dua pasal yang diamanatkan untuk diatur lebih lanjut dengan Peraturan Pemerintah, yaitu Pasal 28 dan 29 mengenai penggabungan, peleburan, pengambil alihan saham.

Pasal 28 UU No. 5 tahun 1999 menyatakan: (1) pelaku usaha dilarang melakukan pengabungan atau peleburan badan usaha yang dapat mengakibatkan terjadinya praktek monopoli dan atau persaingan usaha tidak sehat; (2) pelaku usaha dilarang melakukan pengambilalihan saham perusahaan lain apabila tindakan tersebut dapat mengakibatkan terjadinya praktek monopoli dan atau persaingan usaha tidak sehat; (3) ketentuan lebih lanjut mengenai penggabungan atau peleburan badan usaha yang dilarang sebagaimana dimaksud dalam ayat (1), dan ketentuan mengenai pengambilalihan saham perusahaan sebagaimana dimaksud ayat dalam (2) pasal ini, diatur dalam Peraturan Pemerintah. Pasal 29 UU No. 5 tahun 1999 menyatakan: (1) penggabungan atau peleburan badan usaha, atau pengambilalihan saham sebagaimana dimaksud dalam Pasal 28 yang berakibat nilai aset dan atau nilai penjualannya melebihi jumlah tertentu, wajib diberitahukan kepada Komisi, selambat-lambatnya 30 (tiga puluh) hari sejak tanggal penggabungan, peleburan atau pengambilalihan tersebut; (2) ketentuan tentang penetapan nilai aset dan atau nilai penjualan serta tata cara pemberitahuan sebagaimana dimaksud dalam ayat (1) diatur dalam Peraturan Pemerintah. 
Pada dasarnya merger, akuisisi dan konsolidasi adalah suatu fenomena tersendiri yang dikenal dan berkembang bukan hanya di Indonesia, tapi hampir seluruh belahan dunia sejalan dengan berkembangnya dunia bisnis. Pelaku bisnis berkepentingan dan banyak melaksanakan transaksi Merger, Akuisisi dan konsolidasi, ternyata banyak diantaranya yang belum memahami dengan benar. Pejabat pemerintah dan anggota legislatif membahas dan mendiskusikan serta menyiapkan peraturan perundang-undangan yang berkaitan dengan Merger, Akuisisi dan konsolidasi dengan pemahaman yang berbeda. Badan peradilan juga menghadapi perkara yang berkaitan dengan Merger, Akuisisi dan konsolidasi, jika pengetahuan dan persepsi mereka tentang Merger Akuisisi dan konsolidasi masih gamang tentu dapat diperkirakan bagaimana putusan yang akan diambil. Merger, akuisisi dan konsolidasi selama ini baru dianilisis dari aspek administrative dan prosedural untuk kepentingan pengesahan perubahan Anggaran Dasar dan Rumah Tangga oleh Departemen Hukum dan HAM, jadi pada saat ini sangatlah perlu membuat kajian yang mendalam terkait dengan Ketentuan merger, akuisisi dan konsolidasi dalam perspektif Hukum Persaingan Usaha.

Mengingat bahwa penelitian ini memfokuskan pada Merger, Akusisi dan Konsolidasi dalam perspektif hukum persaiangan usaha, maka yang menjadi permasalahan dalam penelitian ini adalah: (1) bagaimanakah permasalah yang timbul dalam pelaksanaan Merger, Akuisisi dan Konsolidasi dalam perspektif hukum persaingan usaha; (2) bagaimanakah alternatif dan jalan keluar apa yang bisa diambil sehubungan dengan transaksi Merger dan Akuisisi secara terpadu dari segi hukum. Maksud dan tujuan penelitian adalah untuk mencoba mencari pendekatan secara yuridis terkait dengan Merger, Akuisisi dan Konsolidasi dalam perspektif hukum persaingan usaha dan hubungannya dengan hukum positif lain yang juga mengatur ketentuan tentang merger. Kegunaan penelitian ini dapat dilihat baik dari segi teoritis maupun dari segi praktis, yaitu secara teoritis penelitian ini nantinya di harapkan akan bermanfaat dalam perkembangan ilmu hukum dan ekonomi di Indonesia, secara praktis di harapkan hasil penelitian ini di kemudian hari akan berguna dalam menentukan kebijaka yang menyangkut Merger, Akuisisi dan Konsolidasi dalam perspektif hukum persaingan usaha.

\section{METODE PENELITIAN}

Di dalam pelaksanaan penelitian ini akan digunakan metode penelitian yuridis normatif dan pendekatan yuridis empiris dan metode penelitian analitis, serta menggunakan teknik wawancara. Secara yuridis normatif, akan dikumpulkan bahan-bahan dari kepustakaan, maupun dokumendokumen yang berhubungan dengan Merger, Akuisisi dan Konsolidasi. Dari literatur serta dokumendokumen yang ada akan ditemukan fakta-fakta yang berkaitan dengan latar belakang penulisan karya ilmiah ini, selanjutnya diadakan perbandingan-perbandingan fakta yang ditemukan maupun teori-teori hukum yang ada sehingga merupakan suatu metode yuridis normatif dan pendekatan yuridis empiris. Wawancara/interview diadakan setelah didapat gambaran pertama tentang latar belakang dan ditemukannya masalah-masalah dari obyek yang ditinjau. Akhirnya data-data yang diperoleh berupa keterangan maupun dokumen-dokumen pelaksanaan yang dipraktekkan dianalisa secara yuridis, hasil analisa yuridis ini dituangkan dalam tulisan atau makalah ini.

\section{HASIL DAN PEMBAHASAN}

\section{Permasalah yang Timbul dalam Pelaksanaan Merger, Akuisisi Dan Konsolidasi dalam Perspektif Hukum Persaingan Usaha}

Permasalaha awal yang paling mecolok kalau kita menyoroti Merger, Akuisisi Dan Konsolidasi adalah penggunaan istilah. Terdapat banyak peristilahan yang dipergunakan untuk menggambarkan suatu peristiwa yang secara esensi adalah sama. UU No. 40 Tahun 2007 tentang Perseroan Terbatas menggunakan istilah penggabungan, peleburan, dan pengambilalihan. Sedangkan 
Peraturan Pemerintah mengenai Perbankan menggunakan istilah merger, konsolidasi, dan akuisisi. Peraturan Badan Pengawas Pasar Modal No. IX.G.1 mengunakan istilah Penggabungan Usaha atau Peleburan Usaha Perusahaan Publik atau Emiten. Beberapa negara lain menggunakan istilah konsentrasi dan takeover. Meskipun UU No. 5 Tahun 1999 menggunakan istilah penggabungan, peleburan, dan pengambilalihan saham, namun untuk keperluan petunjuk pelaksanaan ini, Komisi menggunakan istilah merger yang didalamnya tercakup juga konsolidasi, akuisisi, penggabungan, peleburan, dan pengambilalihan kecuali secara tegas petunjuk pelaksanaan ini menunjuk kepada salah satu bentuk peristiwa tertentu.Meskipun UU No. 5 Tahun 1999 menggunakan istilah pengambilalihan saham, namun Komisi memandang di dalam istilah pengambilalihan saham terkandungjuga pengertian pengambilalihan aset dan pengambialihan divisi/unit usaha, sehingga istilah pengambilalihan atau pengambilalihan saham dalam petunjuk pelaksanaan ini juga merujuk kepada pengambilalihan aset dan pengambilalihan divisi/unit usaha.

Meskipun UU No. 40 Tahun 2007 telah mendefinisikan apa yang dimaksud dengan penggabungan, peleburan dan pengambilalihan, namun Komisi berpendapat bahwa merger yang dimaksud dalam UU No. 5 Tahun 1999 mencakup pengertian yang lebih luas dibanding dengan definisi dalam UU No. 40 Tahun 2007 yang hanya berlaku bagi Perseroan Terbatas. Untuk itu Komisi perlu untuk menjelaskan gambaran mengenai merger yang dimaksud oleh UU No. 5 Tahun 1999. Merger secara sederhana adalah tindakan pelaku usaha yang mengakibatkan: (1) terciptanya konsentrasi kendali dari beberapa pelaku usaha yang sebelumnya independen kepada satu pelaku usaha atau satu kelompok pelaku usaha; atau (2) beralihnya suatu kendali dari satu pelaku usaha kepada pelaku usaha lainnya yang sebelumnya masing-masing independen sehingga menciptakan konsentrasi pengendalian atau konsentrasi pasar. Merger dapat berupa penggabungan, peleburan, dan pengambilalihan sesuai dengan ketentuan dalam UU No. 40 Tahun 2007 atau berupa merger, konsolidasi, dan akuisisi sesuai dengan ketentuan dalam peraturan perundang-undangan mengenai perbankan ataupun berupa bentuk-bentuk lainnya seperti merger diantara beberapa firma (contohnya firma akuntan publik). Secara umum, merger terjadi apabila dua perusahaan atau lebih yang masingmasing independen, kemudian bergabung menjadi satu perusahaan, baik karena bergabungnya satu perusahaan kepada perusahaan lain, atau beberapa perusahaan tersebut melebur ke dalam satu perusahaan baru, atau beralihnya kendali atas satu perusahaan kepada pelaku usaha lain. Secara grafis, merger dapat digambarkan sebagai berikut:

\section{Bentuk I/Penggabungan}

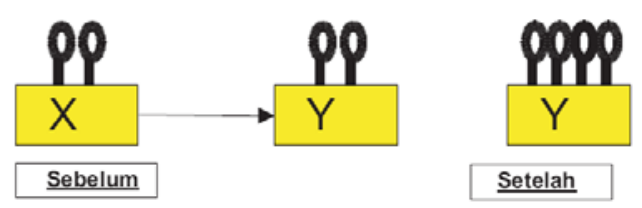

Gambar 1 Bentuk I/Penggabungan

Dalam merger bentuk ini, X menggabungkan dirinya terhadap $\mathrm{Y}$, sehingga secara hukum $\mathrm{X}$ menjadi bubar sedangkan seluruh aktiva dan pasiva X secara hukum beralih kepada Y. Demikian juga dengan pemilik saham, seluruh pemilik saham X secara hukum beralih menjadi pemilik saham Y.

\section{Bentuk II/Peleburan}

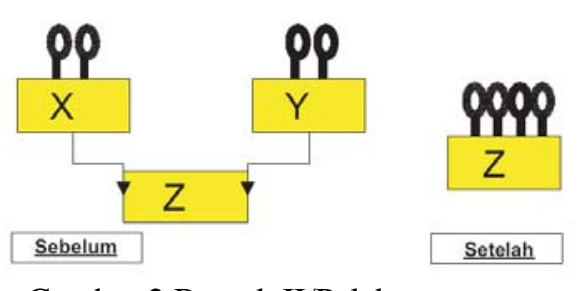

Gambar 2 Bentuk II/Peleburan 
Dalam merger bentuk ini, baik $\mathrm{X}$ dan $\mathrm{Y}$ secara hukum menjadi bubar, sedangkan seluruh aktiva dan pasiva $\mathrm{X}$ dan $\mathrm{Y}$ secara hukum seluruhnya beralih kepada $\mathrm{Z}$, suatu entitas baru. Masingmasing pemilik saham X dan Y kemudian secara hukum beralih menjadi pemilik saham Z.

\section{Bentuk III/Akuisisi Saham}

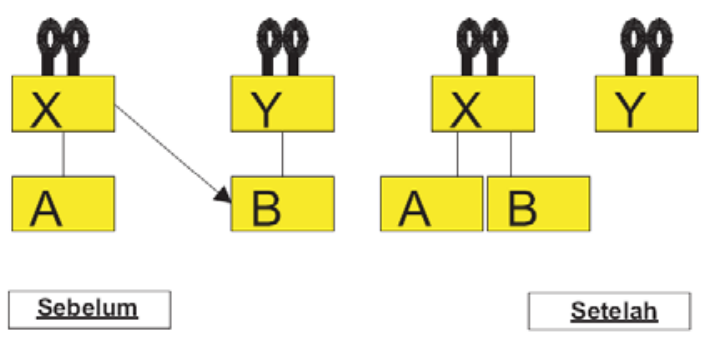

Gambar 3 Bentuk III/Akuisisi Saham

Dalam merger bentuk ini, $\mathrm{X}$ mengambil alih kendali atas $\mathrm{B}$ sehingga $\mathrm{X}$ menjadi pemegang saham dan pengendali dari B. Tidak ada pengalihan aktiva dan pasiva baik dari B kepada X maupun sebaliknya.

\section{Bentuk IV/Akuisisi Aset}

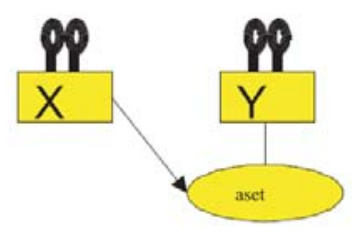

Sebelum

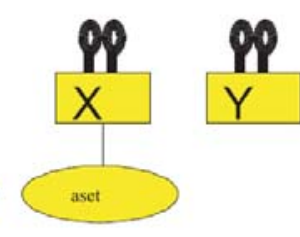

Setelah

Gambar 4 Bentuk IV/Akuisisi Asset

Dalam merger bentuk ini tidak terjadi pengambilalihan saham namun pengambilalihan aset. Aset yang sebelumnya milik Y dibeli oleh X sehingga terjadi perpindahan kendali atas aset tersebut. Melalui akuisisi aset, $\mathrm{X}$ menjadi pengendali aset yang sebelumnya dikendalikan $\mathrm{Y}$.

\section{Bentuk V/Takeover}

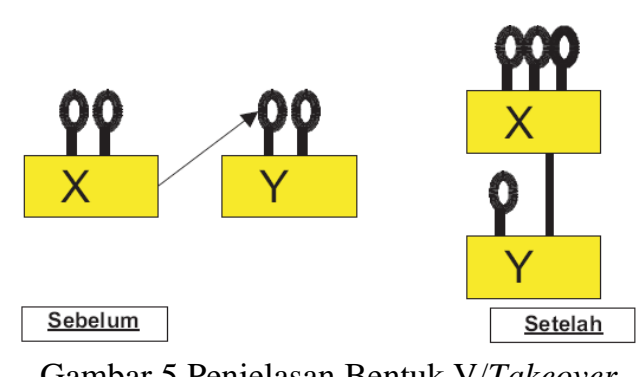

Gambar 5 Penjelasan Bentuk V/Takeover

Dalam merger bentuk ini, $\mathrm{X}$ membeli sebagian besar saham atas $\mathrm{Y}$ langsung dari pemilik sahamnya sehingga $\mathrm{Y}$ menjadi anak perusahaan dari $\mathrm{X}$. Terjadi perpindahan kendali dari pemegang saham Y kepada X. Badan hukum X dan Y tetap hidup tanpa adanya peralihan aktiva dan pasiva dari $\mathrm{X}$ kepada Y maupun sebaliknya. 


\section{Bentuk VI/Public Takeover}

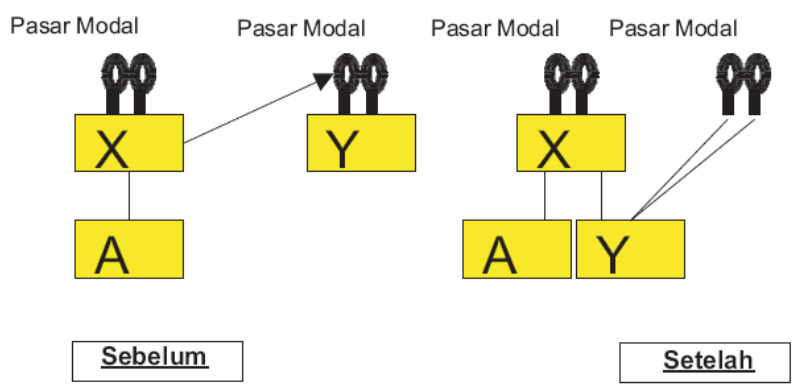

Gambar 6 Bentuk VI/Public Takeover

Merger bentuk ini serupa dengan bentuk V/Takeover, perbedaannya dalam bentuk ini transaksi saham terjadi melalui pasar modal. Y menjadi anak perusahaan X dan X memiliki kendali terhadap Y. Komisi dalam hal ini juga tidak membatasi kemungkinan adanya bentuk-bentuk merger lain yang dilaksanakan selain dari keenam bentuk umum merger di atas. Selama esensi dari merger telah terpenuhi, maka Komisi dapat menggunakan kewenangannya untuk menilai merger tersebut untuk mencegah dampak anti persaingan yang mungkin timbul. Jadi secara umum kita bisa melihat hal-hal yang harus kita perbaiki terlebih dahulu berkaitan dengan istilah-istilah yang digunakan agar tidak menimbulkan pengertian yang beragam di masyarakat.

Permasalahan selanjutnya berkaitan dengan Merger, Akuisisi dan Konsolidasi adalah menyangkut kekutan hukum berkaitan dengan putusan-putusan yang dikeluarkan oleh pihak-pihak yang terkait. Kalau kita amati secara umum ada tiga peraturan yang mendasari aksi korporasi berkaitan dengan merger, akuisisi dan konsolidasi ketentuan pertama adalah Undang-Undang Nomor 40 Tahun 2007 tentang Perseroan Terbatas dimana kita ketahui keputusan tertinggi untuk melakukan suatu aksi korporasi diputuskan dalam RUPS lantas jika Menteri Hukum dan Ham menyetujui perubahan anggaran dasarnya dimana ketentuan ini dapat kita lihat pada Pasal 26 yang menyebutkan bahwa: Perubahan anggaran dasar yang dilakukan dalam rangka Penggabungan atau Pengambilalihan berlaku sejak tanggal: (a) persetujuan Menteri; (b) kemudian yang ditetapkan dalam persetujuan Menteri; atau (c) pemberitahuan perubahan anggaran dasar diterima Menteri, atau tanggal kemudian yang ditetapkan dalam akta Penggabungan atau akta Pengambilalihan.

Jika akhirnya KPPU menolak aksi korporasi itu ini bisa dipastikan terjadi benturan lantas bagaimana KPPU melakukan pembatalan tadi karena secara umum aksi korporasi semacam merger, akuisisi dan konsolidasi ini merupakan suatu strategi bisinis yang dipikirkan secara matang oleh perusahaan dan kalau sudah terlanjur merger maka akan terlalu sulit untuk dilakukan pembatalan. Untuk Bidang Perbankan kalau kita mengacu pada ketentuan Peraturan Pemerintah RI No. 28 Tahun 1999 tentang Merger, Konsolidasi dan Akuisisi Bank dapat kita lihat pada pasal 3, 4 dan 5.

Pasal 3

Merger, Konsolidasi dan Akuisisi Bank dapat dilakukan atas: (a) inisiatif Bank yang bersangkutan; atau (b) permintaan Bank Indonesia; atau (c) inisiatif badan khusus yang bersifat sementara dalam rangka penyehatan perbankan.

\section{Pasal 4}

(1) Merger, Konsolidasi dan Akuisisi Bank yang dilakukan atas inisiatif Bank yang bersangkutan, wajib terlebih dahulu memperoleh izin dari Pimpinan Bank Indonesia; (2) Kewajiban untuk terlebih dahulu memperoleh izin dari Pimpinan Bank Indonesia sebagaimana dimaksud dalam ayat (1), berlaku pula untuk Merger dan Konsolidasi yang dilakukan atas inisiatif badan khusus yang bersifat sementara dalam rangka penyehatan perbankan. 


\section{Pasal 5}

Merger, Konsolidasi dan Akuisisi Bank dilakukan dengan memperhatikan: (a) kepentingan Bank, kreditor, pemegang saham minoritas dan karyawan Bank; dan (b) kepentingan rakyat banyak dan persaingan yang sehat dalam melakukan usaha Bank.

Dengan kondisi di atas, kita bisa melihat bahwa otoritas pemberi kebijakan adalah Bank Indonesia apakah keputusan Merger, Akusisi ataupun Konsolidasi jika dibatalkan olek KPPU tidak menimbulkan benturan, tentunya hal ini yang perlu dicarikan solusinya.

Lebih sulit lagi kalau kita melihat akusisi melalui pasar modal ini yang sulit untuk diawasi, karena hal ini berhubungan dengan cepatnya jual beli saham di pasar modal. Transaksi akuisisi pertama pada pasar modal Indonesia adalah transaksi akuisisi yang dilakukan oleh PT Jakarta International Hotel Development melalui pembelian 100\% saham PT Danayasa Arthatama pada tahun 1990. Setahun setelah transaksi tersebut, Ketua Bapepam mengirimkan Surat dengan nomor S456/PM/1991 kepada seluruh Emiten yang berisi persyaratan yang harus dipenuhi dalam pembelian saham atau penyertaan pada perusahaan lain. Pada perkembangan selanjutnya, surat tersebut bukan saja menjadi acuan bagi pembelian atau penyertaan pada perusahaan lain, tetapi juga menjadi acuan pada setiap transaksi yang nilainya material. Sejak dikeluarkannya surat tersebut, kegiatan akuisisi menjadi semakin sering dilakukan. Namun sayangnya, peraturan yang ada saat itu masih belum cukup untuk melindungi kepentingan publik terutama dalam transaksi akuisisi yang mengandung benturan kepentingan, seperti transaksi akuisisi internal. Pada akuisisi internal, pengambil keputusan mulai dari rencana sampai dengan pelaksanaan transaksi berada pada pihak yang sama sehingga menyebabkan adanya benturan kepentingan. Salah satu contoh akuisisi internal pada saat itu adalah akuisisi yang dilakukan PT Indocement terhadap PT Bogasari, Indofood, dan Wisma Indocement pada tahun 1992. Kelemahan dari peraturan yang ada pada saat itu adalah bahwa keputusan boleh tidaknya suatu transaksi ditentukan oleh suara terbanyak pada RUPS, sedangkan suara terbanyak dimiliki oleh pemegang saham utama yang memang berkepentingan dengan transaksi-transaksi tersebut.

Untuk meningkatkan perlindungan terhadap pemegang saham publik dari transaksi-transaksi yang mengandung benturan kepentingan, maka pada tahun 1996 BAPEPAM mengeluarkan Peraturan BAPEPAM No. IX.E.1 tentang Benturan Kepentingan Transaksi Tertentu. Inti dari peraturan ini adalah bahwa setiap transaksi yang mengandung benturan kepentingan harus mendapat persetujuan pemegang saham independen. Sehingga meskipun pemegang saham utama setuju dengan suatu transaksi, namun apabila pemegang saham independen tidak setuju maka transaksi tersebut tidak dapat dilaksanakan. Adapun yang dimaksud dengan pemegang saham independen adalah pemegang saham yang tidak mempunyai benturan kepentingan dengan suatu transaksi tertentu dan atau bukan merupakan pihak terafiliasi dari direktur, komisaris atau pemegang saham utama yang mempunyai benturan kepentingan atas transaksi tertentu. Seiring dengan semakin banyaknya peraturan yang terkait dengan kegiatan merger dan akuisisi, kegiatan- kegiatan merger dan akusisi menjadi semakin sering dilakukan. Berikut data yang terkait dengan kondisi diatas :

Tabel 1 Daftar Perusahaan Pengakuisisi Tahun 2000-2004

\begin{tabular}{|c|c|c|c|c|}
\hline No & $\begin{array}{l}\text { Kode } \\
\text { saham }\end{array}$ & Perusahaan Pengakuisisi & Mengakuisisi & $\begin{array}{l}\text { Bulan efektif/ } \\
\text { pengumuman }\end{array}$ \\
\hline 1 & DYNA & PT. Dynaplast & PT Sanpak Unggul. & Januari 2000 \\
\hline 2. & BGMT & PT. Siloam Health Care. & PT Baligraha Medikatama & Maret 2000 \\
\hline 3. & ETWA & PT. Eterindo Wahanatama & PT. Surya Malindo Medikatama. & Maret 2000 \\
\hline 4. & SMAR & PT. Smart & PT. Inti Gerak Maju & November 2000 \\
\hline 5. & TLKM & PT. Telkom & PT. Multimedia Nusantara & Desember 2000 \\
\hline 6. & BASS & PT. Bahtera Adimina Samudra & PT. Intergalaxy Delta Fisheries. & Mei 2001 \\
\hline 7. & INDF & PT. Indofood Sukses Makmur & PT. Asia Food Property & Mei 2001 \\
\hline 8. & SIMM & PT. Surya Intrindo Makmur. & PT. Aglo Sama Permata Motor & Mei 2001 \\
\hline 9. & STTP & PT. Siantar Top. & PT. Saritama Tunggal & Agustus 2001 \\
\hline 10. & GGRM & PT. Gudang Garam & PT. Karyadibya Mahardika & Maret 2002 \\
\hline 11 & SRSN & PT. Sarasa Nugraha & PT. Sarasa Mitratama & Mei 2002 \\
\hline 12 & AALI & PT. Astra Agro Lestari & PT. Sinar Tabiora & Oktober 2002 \\
\hline 13 & UNVR & PT. Unilever Indonesia & PT Knorr Indonesia & Juli 2004 \\
\hline 14. & MLPL & PT. Multipolar Corporation & PT. Matahari Putra Prima & Oktober 2004 \\
\hline
\end{tabular}


Tabel 2 Daftar Perusahaan Diakuisisi Tahun 2000-2004

\begin{tabular}{|c|c|c|c|c|}
\hline No. & $\begin{array}{l}\text { Kode } \\
\text { saham }\end{array}$ & Perusahaan Diakuisisi & Diakuisisi Oleh & $\begin{array}{l}\text { Bulan efektif/ } \\
\text { pengumuman }\end{array}$ \\
\hline 1. & AQUA & PT. Aqua Golden Missippi & Danone. & April 2000 \\
\hline 2. & INTP & PT. Indocement Tunggal Perkasa. & Heidelberger Zement AG. & April 2001 \\
\hline 3. & SMBC & $\begin{array}{l}\text { PT. Holcim Indonesia } \\
\text { (Semen Cibinong) }\end{array}$ & Holcim Ltd & $\begin{array}{l}\text { November } \\
2001\end{array}$ \\
\hline 4. & DVLA & $\begin{array}{l}\text { PT. Darya Varya } \\
\text { Laboratories. }\end{array}$ & Far East Drug Co. Ltd & $\begin{array}{l}\text { Desember } \\
2001\end{array}$ \\
\hline 5. & SKLT & PT. Sekar Laut. & BNP Paribas. & Juni 2002 \\
\hline 6. & ALFA & PT. Alfa Retailindo. & PT. Sigmantara Alfindo. & Agustus 2002 \\
\hline 7. & SULI & PT. Sumalindo Lestari Jaya & $\begin{array}{l}\text { PT. Sumber Graha } \\
\text { Sejahtera. }\end{array}$ & Agustus 2002 \\
\hline 8. & ISAT & PT. Indosat & STT Telemedia. & Januari 2003 \\
\hline 9. & PICO & PT. Pelangi Indah Canindo & Hammond Holding Ltd. & Juni 2004 \\
\hline 10. & ADES & PT. Ades Waters Indonesia & Water Partners Bottling & Juli 2004 \\
\hline 11. & MPPA & PT. Matahari Putra Prima & PT. Multipolar Corporation. & Oktober 2004 \\
\hline 12. & SDPC & $\begin{array}{l}\text { PT. Millenium Pharmacon } \\
\text { International. }\end{array}$ & $\begin{array}{l}\text { Esteem Interpoint Sdn } \\
\text { Bhd }\end{array}$ & $\begin{array}{l}\text { Desember } \\
2004\end{array}$ \\
\hline
\end{tabular}

Sumber: BEJ, Indonesian Capital Market Directory

Dengan makin maraknya strategi korporasi seperti akuisisi diatas maka akan menjadi permasalahan tersendiri jika proses di KPPU tidak bisa mengimbangi kondisi kecepatan peralihan saham di Bursa Efek

\section{Alternatif dan Jalan Keluar Apa yang Bisa Diambil Sehubungan dengan Transaksi Merger dan Akuisisi Secara Terpadu dari Segi Hukum}

Pemerintah akhirnya telah menerbitkan Peraturan Pemerintah (PP) No. 57 Tahun 2010 tentang Penggabungan atau Peleburan Badan Usaha dan Pengambilalihan Saham Perusahaan yang Dapat Mengakibatkan Terjadinya Praktek Monopoli dan Persaingan Usaha Tidak Sehat” (“PP 57/2010”). Seperti diketahui, PP tersebut telah lama ditunggu banyak kalangan terutama para pelaku usaha dan juga Komisi Pengawas Persaingan Usaha (“KPPU”). PP ini diharapakan oleh banyak pihak mampu untuk menjawab semua persoalan yang ada berkaitan dengan aksi korporasi yang menyangkut dengan Merger.Akuisisi dan Konsolidasi.

Ujian yang paling berat adalah kasus Akuisisi PT Carefour Indonesia, perkara ini sudah berlangsung sejak Maret 2009. Mulanya KPPU mendapatkan laporan dari berbagai suplier dan vendor atas dugaan pelanggaran terhadap UU No. 5/1999. Perkara ini pun masih diperiksa oleh KPPU. Kini statusnya sudah pada tahap tambahan pemeriksaan lanjutan. KPPU awalnya mengenakan unsur posisi dominan sebagai bentuk pelanggaran dari Carefour, tetapi pada kenyataanya Carrefour tidak menduduki posisi dominan dalam pangsa pasar modern. Dalam pengaturannya, pelaku usaha dikatakan mempunyai posisi dominan jika memiliki pangsa pasar lebih dari 50 persen. Sementara Carrefour hanya memiliki pangsa pasar 17 persen diritel modern dan 7 persen pada ritel nasional. Pada sidang lanjutan KPPU akhirnya menggunakan pasal pamungkasnya yaitu menambahkan dua pasal baru, khususnya Pasal 28 UU No 5 Tahun 1999. KPPU sendiri membidik Carrefour dengan pasal ini karena adanya dugaan pelanggaran terkait akusisi PT Alfa Retailindo Tbk oleh Carrefour.

Dalam perkara PT Carrefour Indonesia, KPPU tidak bisa menggunakan Pasal 28 ayat (2) UU No. 5/1999 untuk menjerat peritel asal Prancis itu. Alasannya ya itu tadi, belum ada PP-nya. Padalah KPPU menilai pengambilalihan (akuisisi) saham PT Alfa Retailindo Tbk membuat Carrefour memiliki market power sehingga terbukti memenuhi Pasal 28 ayat (2). Hanya, pasal itu belum bisa diterapkan karena belum memenuhi syarat formil. "Dampak akusisi terbukti ada kerugian secara nyata, namun belum ada PP yang menyebabkan merger dan akuisisi, belum dapat dikendalikan secara efektif,” kata anggota majelis komisi Anna Maria Tri Anggraini saat membacakan putusan perkara Carrefour tanggal 3 November Tahun 2009, berdasarkan keputusan KPPU No.09/KPPU-U2009 yang 
menyatakan ; Carrefour bersalah karena melanggar pasal 17 ayat 1 mengenai monopoli dan pasal 25 ayat 1 huruf (a) mengenai posisi dominan sesuai UU No 5 tahun 1999 mengenai larangan praktek monopoli dan persaingan usaha tidak sehat. Dari putusan itu, selain mendenda Carrefour sebesar Rp25 miliar, KPPU juga meminta Carrefour untuk melepas seluruh sahamnya di PT Alfaretailindo kepada pihak yang tidak terafiliasi. Pihak Carrefour tidak menerima hal tersebut dan mengajukan gugatan perdata pada Pengadilan Negeri Jakarta Selatan. Permasalahan tersebut disidangkan dengan nomor perkara 1598/pdt.G/2009/ PN. Jkt. Selatan. Pada Rabu 17 Februari 2010, PN Jakarta Selatan membatalkan keputusan KPPU yang menyatakan Carrefour Indonesia telah bersalah melakukan monopoli karena mengakuisisi PT Alfa Retailindo. Komisi Pengawas Persaingan Usaha (KPPU), akhirnya tgl 1 Maret 2010 mengajukan kasasi atas putusan perdata Pengadilan Negeri Jakarta Selatan, yang memenangkan pusat perbelanjaan Carrefour atas putusan KPPU yang memutuskan Carrefour telah melanggar UU No.5/199 tentang Larangan Praktek Monopoli pada 3 November 2009 lalu. Menurut Jurubicara KPPU A. Junaidi, pengajuan kasasi tersebut lantaran KPPU tetap pada putusan Carrefour perkara No. 09/KPPU-L/2009 yang telah dijatuhkan pada 3 November 2009 adalah putusan tepat. "Berdasarkan bukti yang ada menunjukkan bahwa Carrefour setelah mengakuisisi Alfa, telah memenuhi kualifikasi monopoli dan pososi dominan sebesar 57,99\% di pasar pasokan barang/jasa di hipermarket dan supermarket serta terbukti menyalahgunakan monopoli itu.

Kalau kita belajar dari kasus ini jelas ada satu pelajaran menarik yang bisa kita lihat secara legalitas sebetulnya keberadaan UU No. 5 Tahun 1999 itu sudah kuat, namun ternyata Koordinasi antara para pihak yang mengambil keputusan ini yang belum terjadi secara baik, yang saya maksud disini memang sudah harus ada informasi yang akurat berkaitan dengan rencana-rencana Meger, Akuisisi dan Konsolidasi yang bisa diterima oleh KPPU, Depatemen Kehakiman dan BAPEPAM-LK, untuk penerapan hukumnya lebih baik kita gunakan Azas Lex Specialis Derogat Lex Generali yang secara umum kita artikan Hukum yang khusus akan mengalahkan hukum yang umum. Jadi kesimpulannya UU No. 5 Tahun Tahun 1999 ini penerapannya harus didahulukan karena posisinya sebagai Lex Specialis atau Hukum Yang Khusus. Untuk lebih jelasnya berikut hal pertama dan utama yang mestinya dilakukan sebelum melakukan aksi korporasi yang dimaksud: pengusaha bisa melakukan konsultasi terlibih dahulu kepada pihak Komisi hal ini dimungkinkan karena pada pasal 10 Peraturan Pemerintah Republik Indonesia Nomor 57 Tahun 2010 Tentang Pengabungan Atau Peleburan Badan Usaha Dan Pengambilalihan Saham Perusahaan Yang Dapat Mengakibatkan Terjadinya Paktik Monopoli Dan Persaingan Usaha Tidak sehat, di mana bunyi dari pasal tersebut adalah:

Pasal 10

(1) Pelaku Usaha yang akan melakukan Penggabungan Badan Usaha, Peleburan Badan Usaha, atau Pengambilalihan saham perusahaan lain yang berakibat nilai aset dan/atau nilai penjualannya melebihi jumlah tertentu sebagaimana dimaksud dalam Pasal 5 ayat (2) dan ayat (3) dapat melakukan konsultasi secara lisan atau tertulis kepada Komisi; (2) Konsultasi secara tertulis sebagaimana dimaksud pada ayat (1) dilakukan dengan mengisi formulir dan menyampaikan dokumen yang disyaratkan oleh Komisi.

Untuk pasal yang mengatur mengenai kewajiban pemberitahuan atas penggabungan dan peleburan badan usaha serta pengambil alihan saham perusahaan diatur pada pasal : 5, 6, 7 \& 8 yang bunyinya sebagai berikut :

Pasal 5

(1) Penggabungan Badan Usaha, Peleburan Badan Usaha, atau Pengambilalihan saham perusahaan lain yang berakibat nilai aset dan/atau nilai penjualannya melebihi jumlah tertentu wajib diberitahukan secara tertulis kepada Komisi paling lama 30 (tiga puluh) hari kerja sejak tanggal telah berlaku efektif secara yuridis Penggabungan Badan Usaha, Peleburan Badan Usaha, atau Pengambilalihan saham perusahaan. (2) Jumlah tertentu sebagaimana dimaksud pada ayat (1) terdiri atas: (a) nilai aset sebesar Rp 2.500.000.000.000,00 (dua triliun lima ratus miliar rupiah); dan/atau (b) b. nilai penjualan sebesar Rp5.000.000.000.000,00 (lima triliun rupiah). (3) Bagi Pelaku Usaha di 
bidang perbankan kewajiban menyampaikan pemberitahuan secara tertulis sebagaimana dimaksud pada ayat (1) berlaku jika nilai aset melebihi Rp20.000.000.000.000,00 (dua puluh triliun rupiah). (4) Nilai aset dan/atau nilai penjualan sebagaimana dimaksud pada ayat (2) dan ayat (3) dihitung berdasarkan penjumlahan nilai aset dan/atau nilai penjualan dari: (a) Badan Usaha hasil Penggabungan, atau Badan Usaha hasil Peleburan, atau Badan Usaha yang mengambilalih saham perusahaan lain dan Badan Usaha yang diambilalih; dan (b) badan Usaha yang secara langsung maupun tidak langsung mengendalikan atau dikendalikan oleh Badan Usaha hasil Penggabungan, atau Badan Usaha hasil Peleburan, atau Badan Usaha yang mengambilalih saham perusahaan lain dan Badan Usaha yang diambil alih.

Pasal 6

Dalam hal Pelaku Usaha tidak menyampaikan pemberitahuan tertulis sebagaimana dimaksud dalam Pasal 5 ayat (1) dan ayat (3), Pelaku Usaha dikenakan sanksi berupa denda administrative sebesar Rp1.000.000.000,00 (satu miliar rupiah) untuk setiap hari keterlambatan, dengan ketentuan denda administratif secara keseluruhan paling tinggi sebesar Rp25.000.000.000,00 (dua puluh lima miliar rupiah).

\section{Pasal 7}

Kewajiban menyampaikan pemberitahuan secara tertulis sebagaimana dimaksud dalam Pasal 5 ayat (1) dan ayat (3) tidak berlaku bagi Pelaku Usaha yang melakukan Penggabungan Badan Usaha, Peleburan Badan Usaha, atau Pengambilalihan saham antar perusahaan yang terafiliasi.

Pasal 8

(1) Pemberitahuan secara tertulis sebagaimana dimaksud dalam Pasal 5 ayat (1) dan ayat (3) dilakukan dengan cara mengisi formulir yang telah ditetapkan oleh Komisi. (2) Formulir sebagaimana dimaksud pada ayat (1) paling sedikit memuat: (a) nama, alamat, nama pimpinan atau pengurus Badan Usaha yang melakukan Penggabungan Badan Usaha, Peleburan Badan Usaha, atau Pengambilalihan saham perusahaan lain; (b) ringkasan rencana Penggabungan Badan Usaha, Peleburan Badan Usaha, atau Pengambilalihan saham perusahaan; dan (c) nilai aset atau nilai hasil penjualan Badan Usaha. (3) Formulir sebagaimana dimaksud pada ayat (1) wajib: (a) ditandatangani oleh pimpinan atau pengurus Badan Usaha yang melakukan Penggabungan Badan Usaha, Peleburan Badan Usaha, atau Pengambilalihan saham perusahaan lain; dan (b) dilampiri dokumen pendukung yang berkaitan dengan Penggabungan Badan Usaha, Peleburan Badan Usaha, atau Pengambilalihan saham perusahaan.

Setelah apa yang sudah dipersyaratkan oleh KPPU dipenuhi seperti ketentuan diatas maka proses legalitas yang lain bisa dilaksanakan mulai dari aksi korporasinya lewat Bursa Efek Indonesia yang proses legalitasnya lewat pengesahan anggaran dasarnya di Departemen Hukum Dan Ham sehingga secara umum tidak bermasalah.

\section{PENUTUP}

Pada dasarnya jika berkaitan dengan suatu kasus persaingan usaha tidak sehat maka KPPU sebaiknya tidak terjebak pada keseragaman istilah, karena yang terpenting adalah aspek ada tidaknya praktek monopoli dan atau persaingan usaha tidak sehat di dalam staregi korporasi yang dilakukan oleh badan usaha, karena memang secara umum berkaitan dengan Merger dan Akuisisi ini dalam peraturan KPPU No 1/2009 tidak identik dengan pengabungan, peleburan dan pengambilalihan sebagaimana diatur dalam UU No.40 tahun 2007 tentang PT. Merger dan Akuisisi menurut peraturan KPPU No 1/2009 juga tidak sama dengan Merger, Konsolidasi, dan Akuisisi yang diatur dalam ketentuan peraturan perundang-undangan di bidang perbankan ataupun di pasar modal. Merger dan Akuisisi menurut Peraturan KPPU No. 1/ 2009 akan mencakup penggabungan, peleburan, konsolidasi, business combination, take-over dengan segala bentuk penamaan dan cara yang dilakukan oleh pelaku usaha yang dapat mengakibatkan terjadinya praktik monopoli dan atau persaingan usaha tidak sehat. 
Merger, Akuisisi maupun Konsolidasi dalam prakteknya bisa terkait dengan berbagai macam regulasi serta otoritas birokrasi. Misal regulasi perbankan yang otoritas regulasinya ada pada Bank

Indonesia, Perseroan Terbatas regulasinya mengacu kepada UU Perseroan terbatas otoritas birokrasinya bisa ke Menteri Kehakiman dan sekaligus ke Bapepam jika jenis PT-nya sudah listing di Bursa Efek Indonesia. Jadi secara umum Peraturan KPPU harus dijadikan acuan pertama dalam menilai apakah strtegi korporasi yang dilakukan oleh suatu perusahaan melanggar hukum persaingan usaha atau tidak disamping itu juga sistem informasi yang terintegrasi sehingga secara cepat bidangbidang yang terkait tahu menganai perencanaan, pelaksanaan serta keputusan terkait dengan strategi korporasi yang dilakukan oleh perusahaan sehingga mampu meminimalisir kesalahan-kesalahan terkait dengan merger, akuissi dan konsolidasi yang berakibat dibatalkan olek KPPU.

\section{DAFTAR PUSTAKA}

Republik Indonesia, (2007) Undang-undang No. 40 Tahun 2007 tentang Perseroan Terbatas

Republik Indonesia, (1999) Undang-Undang No. 5 Tahun 1999 tentang Larangan Praktek Monopoli dan Persaingan Usaha Tidak Sehat.

Republik Indonesia (2009) Peraturan KPPU No. 1 Tahun 2009 tentang Pra-Notifikasi Penggabungan, Peleburan dan Pengambilalihan.

\section{RIWAYAT PENULIS}

Paulus Aluk Fajar Dwi Santo lahir di kota Probolinggo pada 17 Juni 1967. Penulis menamatkan pendidikan S1 di Universitas Negeri Jember pada tahun 1992 dalam bidang Hukum Perdata dan S2 di Universitas Tarumanagara dalam bidang Hukum Bisnis pada tahun 2005. Saat ini bekerja sebagai Dosen dan Pembina Organisasi Kemahasiswaan di Universitas Bina Nusantara. 